\title{
Alterations of Ovarian 4-Pregnen-20 $\alpha$-ol-3-one and Adrenal Corticosterone at Various Times after Hypophysectomy, and the Ovarian Response to Exogenous Pituitary Gonadotropin
}

\author{
Masanao HIRAI, Yoshiko MASUBUCHI AND TAKESHI NAKAO \\ Department of Pharmacology, The Jikei University \\ School of Medicine. Tokyo
}

\begin{abstract}
Synopsis
1. Ovarian $20 \alpha-\mathrm{OH}-\mathrm{P}$ was determined at 5, 15, 30, $60 \mathrm{~min}, 2,5,12,24 \mathrm{hr}$ and 2, 3, $4,5,7,10$ days after hypophysectomy in Wistar rats aged 7-8 weeks. Corticosterone in the adrenal was estimated in comparative study. Results indicated two distinct facts; one is that endogenous $20 \alpha$-OH-P-genesis seems still lasting at least 4 days in the ovary after pituitary removal and, the other is that, in the adrenal gland, corticoidogenesis may immediately decline within $60 \mathrm{~min}$ after the operation. That the most appropriate time after hypophysectomy must be 6 day when the ovary is no longer secreting significant quantity of ovarian steroid but when little sensitivity to gonadotropin appears to have been lost. In contrast, the appropriate time for ACTH bioassy is at least one hour after hypophysectomy. It is unlikely that pituitary support of ovarian steroidogenesis or function is essential. Additionaly, ovarian function was suppressed by the pentobarbital anesthesia.

2. FSH (NIH-S-3, $10 \mu \mathrm{g} / 0.1 \mathrm{~m} l$ saline, i.v.) or LH (NIH-S-10, $10 \mu \mathrm{g} / 0.1 \mathrm{ml}$ saline, i.v.) or FSH $(10 \mu \mathrm{g})$ plus $\mathrm{LH}(10 \mu \mathrm{g})$ was injected, without anesthesia to rats 6 days after hypophysectomy. They were decapitated without anesthesia at 5, 10, 30, 60, 120 and 180 min after the injection. Results showed that FSH alone can stimulate production of ovarian $20 \alpha-\mathrm{OH}-\mathrm{P}$, significantly increasing the steroid content and concentration up to the level of intact animals as well as LH, and the combination of FSH plus LH likewise caused marked elevation of $20 \alpha-\mathrm{OH}-\mathrm{P}$ level. One type of synergism was manifested. In addition, ovarian response to exogenous pituitary gonadotropin(s) as evidenced by the $20 \alpha-\mathrm{OH}-\mathrm{P}$ level was very fast, taking place within $5 \mathrm{~min}$. These results suggests that FSH, like $\mathrm{LH}$, is indispensable for progestin biosynthesis in the rat ovary. Further discussion was made on the relationship between FSH and $20 \alpha-\mathrm{OH}-\mathrm{P}$ in the ovulatory process.
\end{abstract}

A clear understanding of the mechanisms underlying biological action of 4-pregnen-20 $\alpha$ ol-3-one $(20 \alpha-\mathrm{OH}-\mathrm{P})$ is not available at the present time. Hilliard et al. (1967) suggested that $20 \alpha-\mathrm{OH}-\mathrm{P}$ acts as positive feedback agent to prolong and heighten $\mathrm{LH}$ discharge in the mated rabbit. Previous studies from our laboratory have dealt with determination of

Received for publication August 6, 1971.

Supported in part by Grant for Scientific Research from the Ministry of Education, Japan. Presented in part at the annual meeting of the 42nd Japan Pharmacological Society, 1969. mechanisms for action of synthetic progestin as ovulation controller associated with $20 \alpha$ $\mathrm{OH}-\mathrm{P}$ function and with the determination of the steroid dynamics within ovarian venous blood, peripheral blood and ovarian tissue concerning with reproductive cycles (Nakao et al., 1967; Hirai et al., 1968a, b; 1969a; 1970a). These studies, recently summarized (Hirai and Nakao, 1970), have led to the conclusion that the secretion of $20 \alpha-\mathrm{OH}-\mathrm{P}$ was found greater than that of progesterone $(\mathrm{P}<0.001)$ in intact rat ovarian venous blood and that the synthetic progestin was 
effective on $20 \alpha-\mathrm{OH}-\mathrm{P}$ in ovarian tissue and ovarian venous blood in the rat. Most striking change of all was that norethynodrel treated rats produced a significant decrease in secretion of $20 \alpha-\mathrm{OH}-\mathrm{P}$ without any significant change in progesterone levels. In our morphological studies (Sekiyama et al. 1968a, b), data support that $20 \alpha-\mathrm{OH}-\mathrm{P}$ may be secreted from either the interstitial cell or the follicular cell. In electron microscopic studies, however, it seems to be secreted mainly from the former, which appeared to be markedly inhibited by the administration of norethynodrel (Sekiyama et al. 1969). Further, synthetic progestin acts as an inhibitor of FSH and/or LH release as evidenced by ovarian $20 \alpha-\mathrm{OH}-\mathrm{P}$ levels in intact rat, and that synthetic progestin dose interfere directly in vivo with the response of the ovarian $20 \alpha-\mathrm{OH}-\mathrm{P}$ synthesis to exogenous FSH plus LH in the hypophysectomized rat, and it does act directly on the ovarian $20 \alpha$ $\mathrm{OH}-\mathrm{P}$ biosynthesis. These results suggest that the effect of synthetic progestin on the mechanisms of ovulation inhibitory action and/or implantation inhibitory action may involve inhibitory action of the biosynthesis of $20 \alpha$ $\mathrm{OH}-\mathrm{P}$.

No attempt was made to establish what change occur in ovarian $20 \alpha-\mathrm{OH}-\mathrm{P}$ at various times after the hypophysectomy and whether or not FSH or LH or FSH plus LH can induce $20 \alpha-\mathrm{OH}-\mathrm{P}$ genesis in the ovary. In addition, the pituitary and uterus appear to exert a regulative role in ovarian function (Smith and White, 1931; du Mesnil du Buisson, 1961; Ginther, 1967; Spies et al., 1967; Hilliard et al., 1968). These are still remained unknowen in rat.

Hypophysectomy in general causes a depletion of corticosterone from adrenal glands within a short time after the operation in rat, and it does not be recovered. On the other hand there appears to be no information in the literature on the changes of ovarian $20 \alpha-\mathrm{OH}-\mathrm{P}$ levels after hypophysectomy. It would be of interest to define more clearly the different role of steroidogenesis of these endocrine organs in the process following hypophysectomy.

Purpose of this study was (1) to determine alteration of ovarian $20 \alpha-\mathrm{OH}-\mathrm{P}$ at various time intervals after the hypophysectomy in comparison with that of adrenal corticosterone, and (2) to determine, in the hypophysectomized rats, whether FSH or $\mathrm{LH}$ alone has an effect on the biosynthesis of ovarian $20 \alpha-\mathrm{OH}-\mathrm{P}$ and whether the combination of FSH plus LH establishes complete ovarian $20 \alpha-\mathrm{OH}-\mathrm{P}$ genesis. Fortunately, with the advent of more sensitive and highly specific technique (Hirai et al., 1969b), the determination of $20 \alpha-\mathrm{OH}-\mathrm{P}$ levels in tissue and/or blood is now permitted up to nano gram.

\section{Materials and Methods}

\section{Animals}

Female rats of the Wistar strain purchased from Japan CLEA Laboratory (Tokyo, Japan), aged 36-45 days were fed Purina Laboratory Chow and water ad libitum. The rats were housed in a constant temperature $\left(23-24^{\circ} \mathrm{C}\right)$ and artificially lighted $(6.00 \mathrm{a} . \mathrm{m}$. to 6.00 p.m.) room for at least three weeks before starting the experiments. Hypophysectomy was performed by the parapharyngeal route under pentobarbital sodium anesthesia ( $3 \mathrm{mg}$ per $100 \mathrm{~g}$ Body Weight, i.p.). Each rat demonstrated at least four regular cycles before it was operated. Rats were hypophysectomized between $9.30 \mathrm{a}$ am. and $11.00 \mathrm{a} . \mathrm{m}$. at various stages of the estrous cycle. The sham operation was carried out up to incision of the connective tissue membrane around the pituitary. Making of a small hole in the cranial skull bone and anesthesia with pentobarbital were all carried out identically with true hypophysectomy.

\section{Hypophysectomized Rats without Treatment}

Ovarian $20 \alpha-\mathrm{OH}-\mathrm{P}$ was determined at $5,15,30$, $60 \mathrm{~min}, 2,5,12,24 \mathrm{hr}$ and 2, 3, 4, 5, 7, 10 days after hypophysectomy. Pairs of ovaries were quickly removed from the hypophysectomized rats after decapitation without anesthesia. In comparative studies, pairs of adrenals were also rapidly removed from these animals for corticosterone determination.

Pituitary Gonadotropin Administration to Hypophysectomized Rats

Results from the first experiments for the significant alteration of $20 \alpha-\mathrm{OH}-\mathrm{P}$ levels show that a ap- 
propriate time (more than 4 days) after hypophysectomy is necessary for starting any other kind of experiments. Subsequently, in this experiments, rats were used at 6 days after hypophysectomy. FSH (NIH-S-3, $10 \mu \mathrm{g} / 0.1 \mathrm{~m} l$ saline, i.v.), LH (NIH-S-10, $10 \mu \mathrm{g} / 0.1 \mathrm{~m} l$ saline, i.v.) and combination of FSH $(10 \mu \mathrm{g})$ plus $\mathrm{LH}(10 \mu \mathrm{g})$ (these were mixed just before use) were injected into their exposed saphenous vein, respectively. Groups of rats injected with saline alone served as the controls. The injection was performed without anesthesia and each group consisted of, at least, 15 animals. Rats were immediately decapitated without anesthesia at 5, 10, 30, 60, 120 and 180 min after the injection. Pairs of ovaries were removed, cleaned, weighed rapidly.

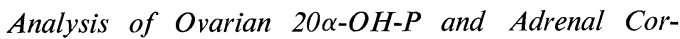
ticosterone

For analysis of $20 \alpha-\mathrm{OH}-\mathrm{P}$, a quantitative microfluorometric estimation with divided thin layer chromatographic separation were used. This technique was reported in details elsewhere (Hirai et al. 1969b). In determination of adrenal corticosterone, a micro-paper chromatographic separation and fluorometric technique were used. These were also described elsewhere (Nakao and Hirai, 1961). Fluorescent mesurements were made in an AmincoBowman Spectrofluorophotometer, Model 4-8106, SPF, equipped with Xenon No. 416-992 lamp.

\section{Results}

\section{Intact Rats}

Experiment 1: Estrous cycle variation in ovarian $20 \alpha-O H-P$ and adrenal corticosterone in the intact rats
For the examination of estrous cycle variation, intact rats were divided into groups, diestrous and proestrous rats. Contents and concentrations of ovarian $20 \alpha-\mathrm{OH}-\mathrm{P}$ and adrenal corticosterone were shown in Table 1. $20 \alpha$-OH-P levels were $0.136 \pm 0.0124 \mu \mathrm{g} /$ pair of ovaries, $2.022 \pm 0.1775 \mu \mathrm{g} / \mathrm{g}$ ovary in diestrous rats and $0.129 \pm 0.0117 \mu \mathrm{g} /$ pair ov., $1.883 \pm 0.1936 \mu \mathrm{g} / \mathrm{g}$ ov. in proestrous rats. Corticosterone levels was $1.639 \pm 0.3336 \mu \mathrm{g} /$ pair of adrenals, $27.694 \pm 5.2511 \mu \mathrm{g} / \mathrm{g}$ adrenal in diestrous rats and $1.507 \pm 0.2261 \mu \mathrm{g} /$ pair adr., $25.900 \pm 3.3282 \mu \mathrm{g} / \mathrm{g}$. adr. in proestrous rats. These steroid levels were not significantly different between diestrus and proestrus in the Wistar strain aged 56-63 days. It should, however, be noted in this case that, in the uterine weight, proestrous group $(568.2 \pm$ $20.53 \mathrm{mg})$ showed significantly $(\mathrm{P}<0.001)$ higher values than diestrous group $(254.5 \pm$ $10.57 \mathrm{mg}$ ). The ovarian, adrenal and body weights showed no significantly difference between the two groups.

II. Effects of Hypophysectomy (Hypox)

Experiments 2: Contents and concentrations of ovarian 20 $\alpha-O H-P$ and adrenal corticosterone in rats at various times after the hypophysectomy

To test whether pituitary support of ovarian function was essential, contents of ovarian

Table 1. Estrous cycle variation on ovarian 4-pregnen-20 $\alpha$-ol-3-one and adrenal corticosterone by the intact rat

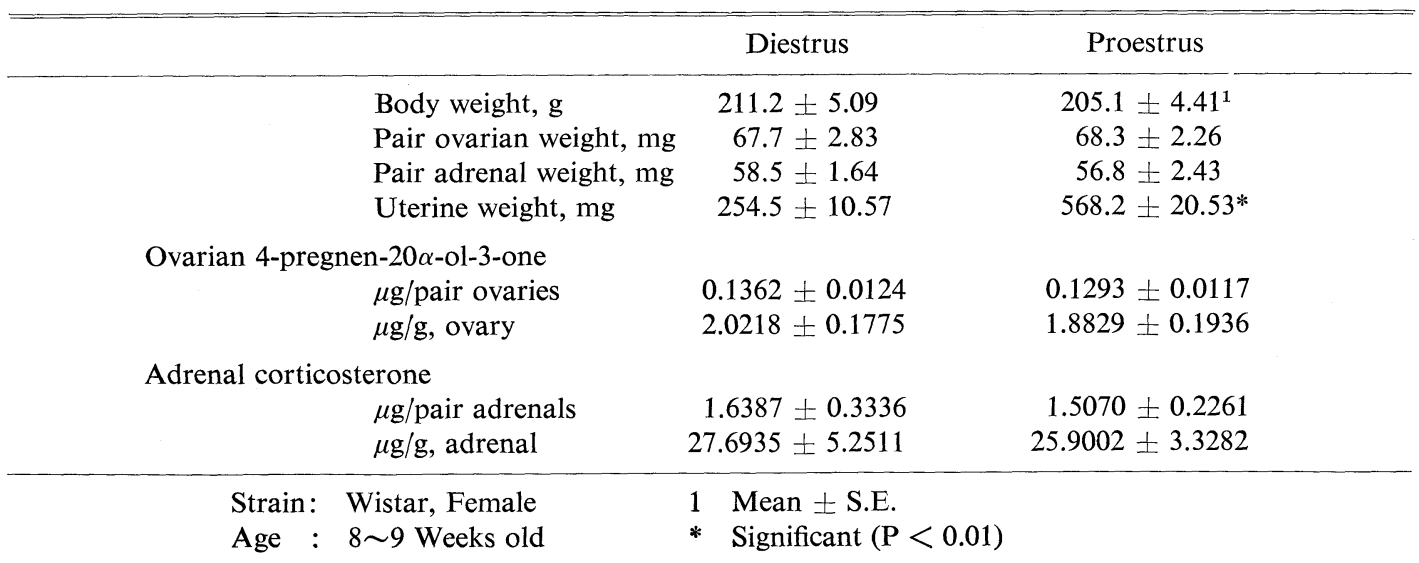




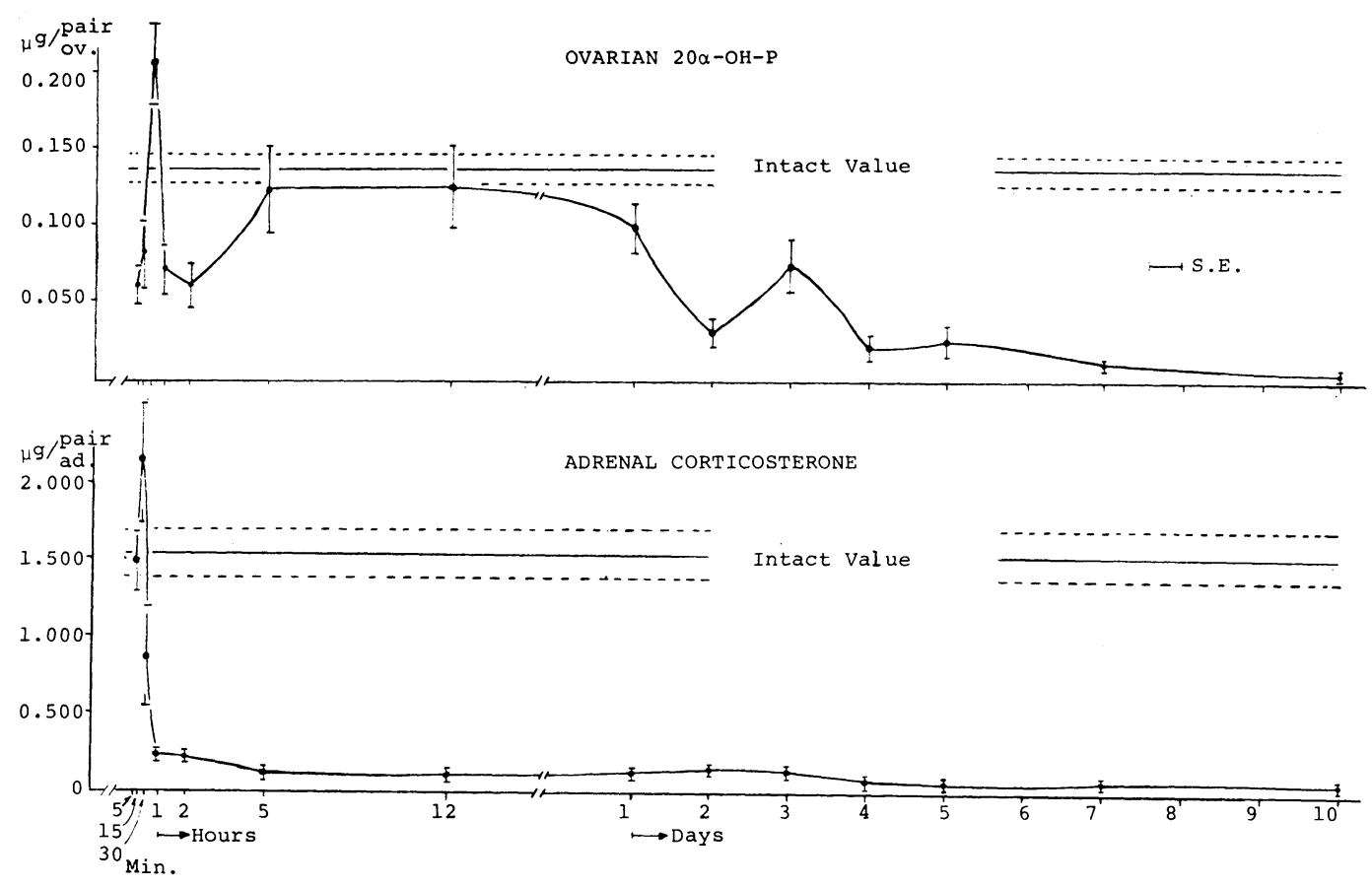

Fig. 1. Contents of ovarian 4-pregnen-20 $\alpha$-ol-3-one and adrenal corticosterone in rat at various times after the hypophysectomy.

$20 \alpha-\mathrm{OH}-\mathrm{P}$ was determied at various time intervals from $5 \mathrm{~min}$ to 10 days after hypophysectomy and, in comparative studies, estimation was made in the adrenal corticosterone contents at various times after the operation. These were shown in Figure 1. Within $5 \mathrm{~min}$ after the operation $20 \alpha-\mathrm{OH}-\mathrm{P}$ content was shown significantly $(\mathrm{P}<0.01)$ lower $(0.062 \pm 0.0126 \mu \mathrm{g} /$ pair ov. $)$ than that of the intact animal $(0.136 \pm 0.0066 \mu \mathrm{g} /$ pair ov.). At $15 \mathrm{~min}$, no significant difference was found between hypox $(0.083 \pm 0.0274 \mu \mathrm{g} /$ pair ov.) and intact animals, but at $30 \mathrm{~min}$, the value in the operated animals $(0.210 \pm 0.0316$ $\mu \mathrm{g} /$ pair ov.) showed significant increase $(\mathrm{P}<0.01)$ over that of the intact animal. At one $\mathrm{hr}(0.070 \pm 0.0177 \mu \mathrm{g} /$ pair ov. $)$ and $2 \mathrm{hr}$ $(0.061 \pm 0.0174 \mu \mathrm{g} /$ pair ov.) after the operation, it was significantly decreased $(\mathrm{P}<0.01)$ from that of the intact animal. Then, at 5 $(0.124 \pm 0.0310 \mu \mathrm{g} /$ pair ov. $), 12(0.127 \pm$ $0.0299 \mu \mathrm{g} /$ pair ov.) and $24(0.100 \pm 0.0156$ $\mu \mathrm{g} /$ pair ov.) hr after the operation, it was showen not significantly different from that of the intact animal. The content of $20 \alpha-\mathrm{OH}-\mathrm{P}$ on day 2 was significantly decreased $(0.031 \pm$ $0.0063 \mu \mathrm{g} /$ pair ov. $)(\mathrm{P}<0.01)$ as compared with that of intact animals. But on day 3 the value $(0.077 \pm 0.0201 \mu \mathrm{g} /$ pair ov. $)$ was elevated up to a levels that of intact animals, thereafter decreasing steadily to $0.023 \pm$ $0.0045 \mu \mathrm{g} /$ pair ov. (on day 4), $0.030 \pm 0.0106$ $\mu \mathrm{g} /$ pair ov. (on day 5), $0.012 \pm 0.0035 \mu \mathrm{g} /$ pair ov. (on day 7), and $0.009 \pm 0.0009 \mu \mathrm{g} /$ pair ov. (on day 10) after the operation.

In contrast with ovarian $20 \alpha-\mathrm{OH}-\mathrm{P}$, adrenal corticosterone level after the operation was found to decrease abruptly without fluctuation except at $15 \mathrm{~min}$, at which time slight but non-significant elevation was observed. (Fig. 1). Further, at $30 \mathrm{~min}$, it seems lower than in intact animals $(1.515 \pm 0.1542 \mu \mathrm{g} /$ pair adr. $)$ but not significantly. It was very low from 60 $\min (0.227 \pm 0.0126 \mu \mathrm{g} /$ pair adr. $)$ to 10 days 

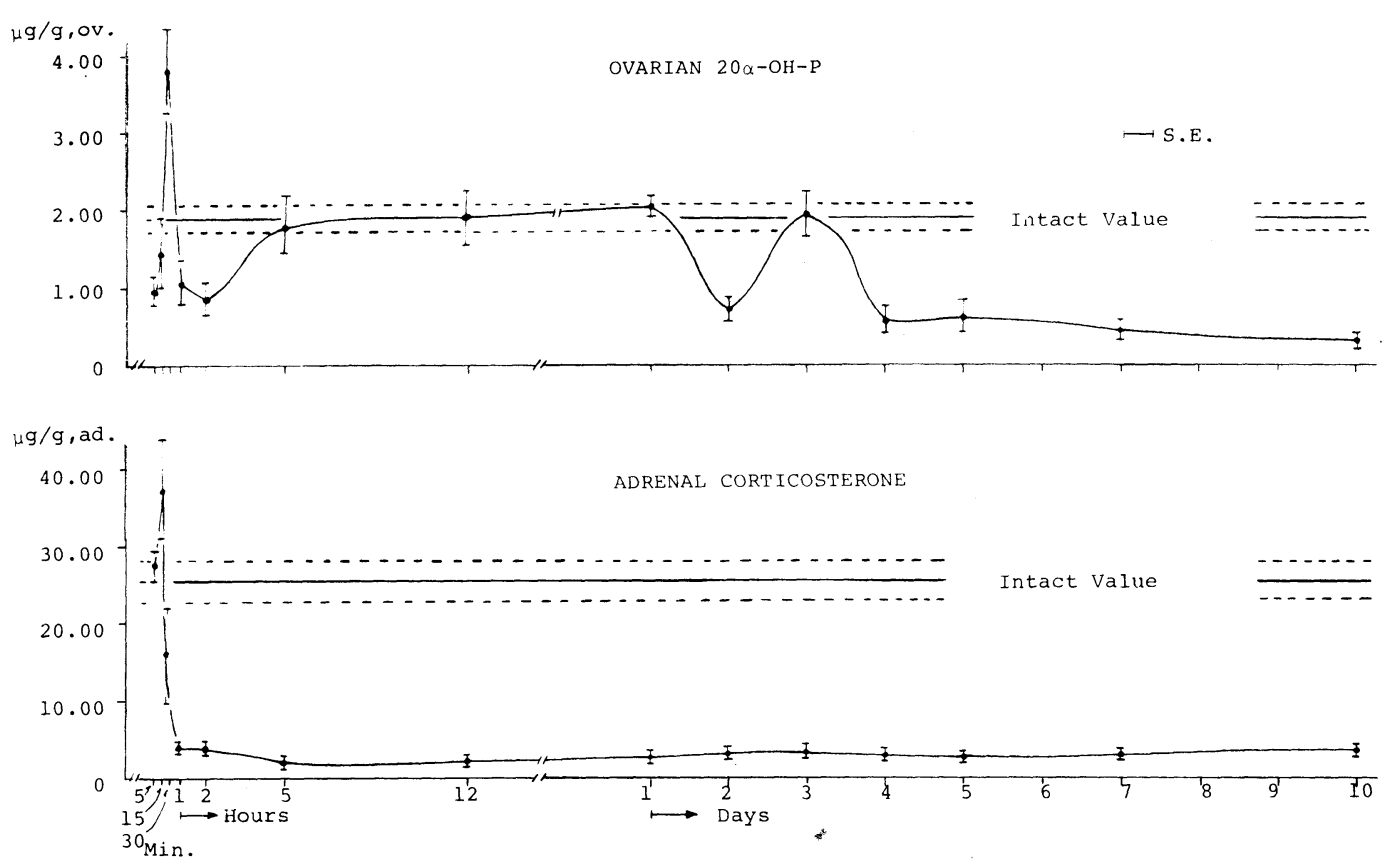

Fig. 2. Concentrations of ovarian 4-pregnen-20 $\alpha$-ol-3-one and adrenal corticosterone in rat at various times after the hypophysectomy.

$(0.078 \pm 0.0157 \mu \mathrm{g} /$ pair adr. $)$ after the hypophysectomy. Alterations of ovarian $20 \alpha-$ $\mathrm{OH}-\mathrm{P}$ and adrenal corticosterone concentrations were almost identical to those of their contents, respectively, as showen in Figure 2.

From these experiments, it should be emphasized that the alteration of ovarian $20 \alpha-\mathrm{OH}-\mathrm{P}$ levels was absolutely different from that of adrenal corticosterone levels in rats at various times intervals after hypophysectomy, although each of them showed a clear trend to decrease with following pituitary removal.

Experiment 3: Contents and concentrations

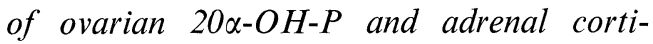
costerone in rats at various short times after hypophysectomy as compared with the sham operation

Data obtained from hypophysectomized rats were shown in Figure 3 where the $20 \alpha$ $\mathrm{OH}-\mathrm{P}$ contents $(0.210 \pm 0.0316 \mu \mathrm{g} /$ pair ov. $)$ were found significantly increased $(\mathrm{P}<0.05)$ at $30 \mathrm{~min}$ after the operation as compared with those of intact animals $(0.136 \pm 0.0066$ $\mu \mathrm{g} /$ pair ov.). In contrast to this, significantly low levels of $20 \alpha-\mathrm{OH}-\mathrm{P}$ were found in the sham operated animals $(0.053 \pm 0.0038 \mu \mathrm{g} /$ pair ov.) at $30 \mathrm{~min}$ after the operation as compared with those of both intact $(\mathrm{P}<$ $0.001)$ and hypophysectomized $(\mathrm{P}<0.001)$ animals. Furthermore, the content of $20 \alpha-\mathrm{OH}-$ $P$ in the sham operated group was significantly lower at $5(0.0058 \pm 0.0024 \mu \mathrm{g} /$ pair ov. $), 15$ $(0.051 \pm 0.0017 \mu \mathrm{g} /$ pair ov. $), \quad 60 \quad(0.067 \pm$ $0.0068 \mu \mathrm{g} /$ pair ov.) and $120 \mathrm{~min}(0.064 \pm$ $0.0033 \mu \mathrm{g} /$ pair ov.) after the operation than those of intact group. In comparison of samples from sham operated and hypophysectomized animals, no significant differences were found in the $20 \alpha-\mathrm{OH}-\mathrm{P}$ contents at $5,15,60$ and $120 \mathrm{~min}$ after the operation with exception at $30 \mathrm{~min}$ as mentioned above.

In an experiment on adrenal corticosterone levels as a function of short times after hypophysectomy in Figure 3, contents of corticosterone were found lower in the sham operated rats at 5 and $15 \mathrm{~min}$ after the opera- 

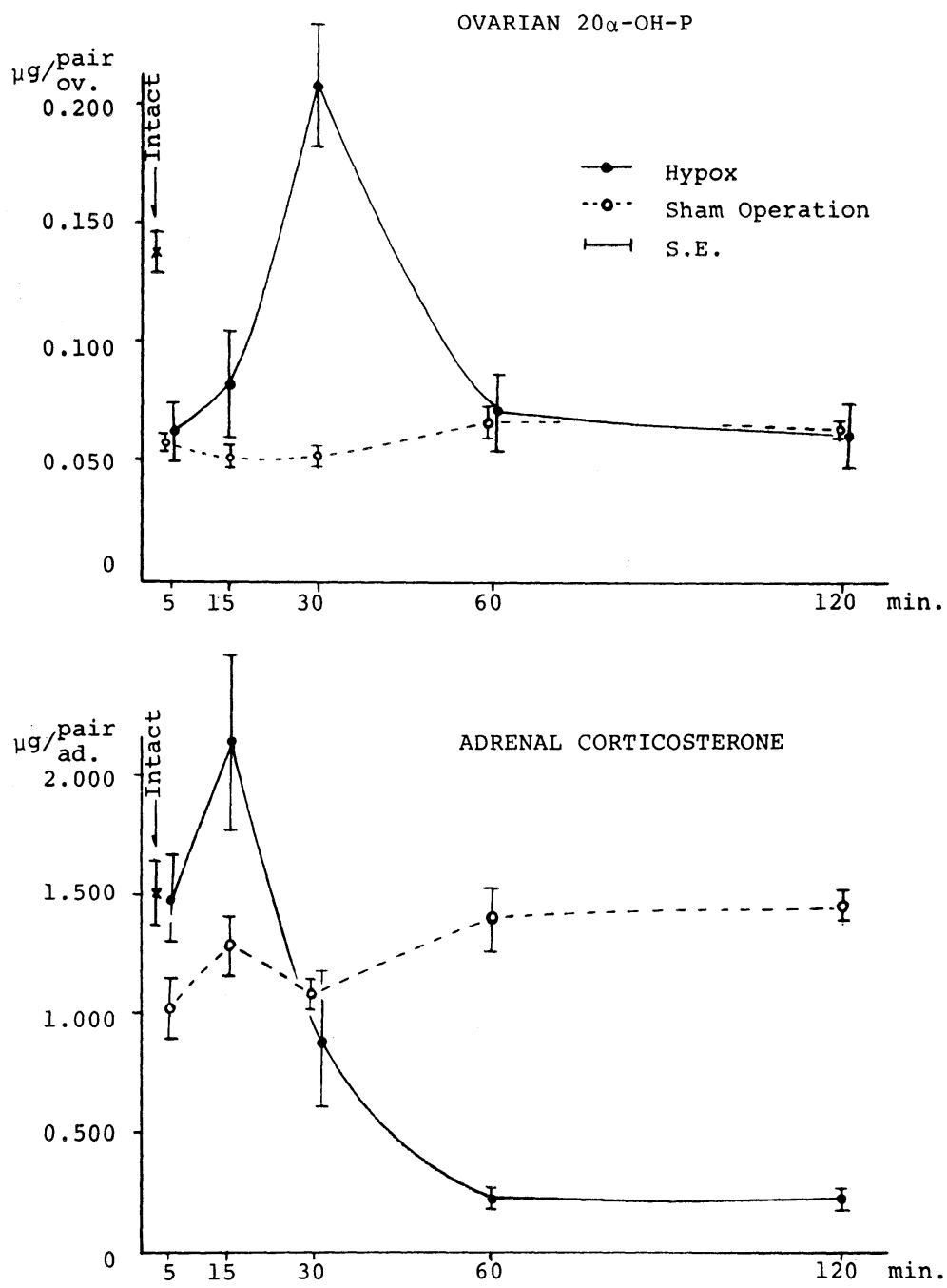

Fig. 3. Contents of ovarian 4-pregnen-20 $\alpha$-ol-3-one and adrenal corticosterone in rat at various times after the hypophysectomy as compared with sham operation.

tion than in both intact and hypophysectomized rats. There were, however, no significant differences between these 3 groups (hypox, sham op., intact) in the adrenal corticosterone contents at $30 \mathrm{~min}$ after the operation. In contrast to the more progressive decrease of adrenal corticosterone contents from 15 to $120 \mathrm{~min}$ in hypox rats than in intact rats, no significant difference was found in the adrenal corticosterone contents between the sham operated and intact rats 15 to 120 min. Thus, significant differences occurred in the adrenal corticosterone contents from 60 min after the operation between the sham operated $(1.407 \pm 0.1506 \mu \mathrm{g} /$ pair adr. at 60 min) and hypophysectomized animals $(0.227 \pm 0.0126 \mu \mathrm{g} /$ pair adr. at $60 \mathrm{~min})$.

Results in the concentration and content of $20 \alpha-\mathrm{OH}-\mathrm{P}$ showed a clearly identical trend as above reported, and so did adrenal corti- 

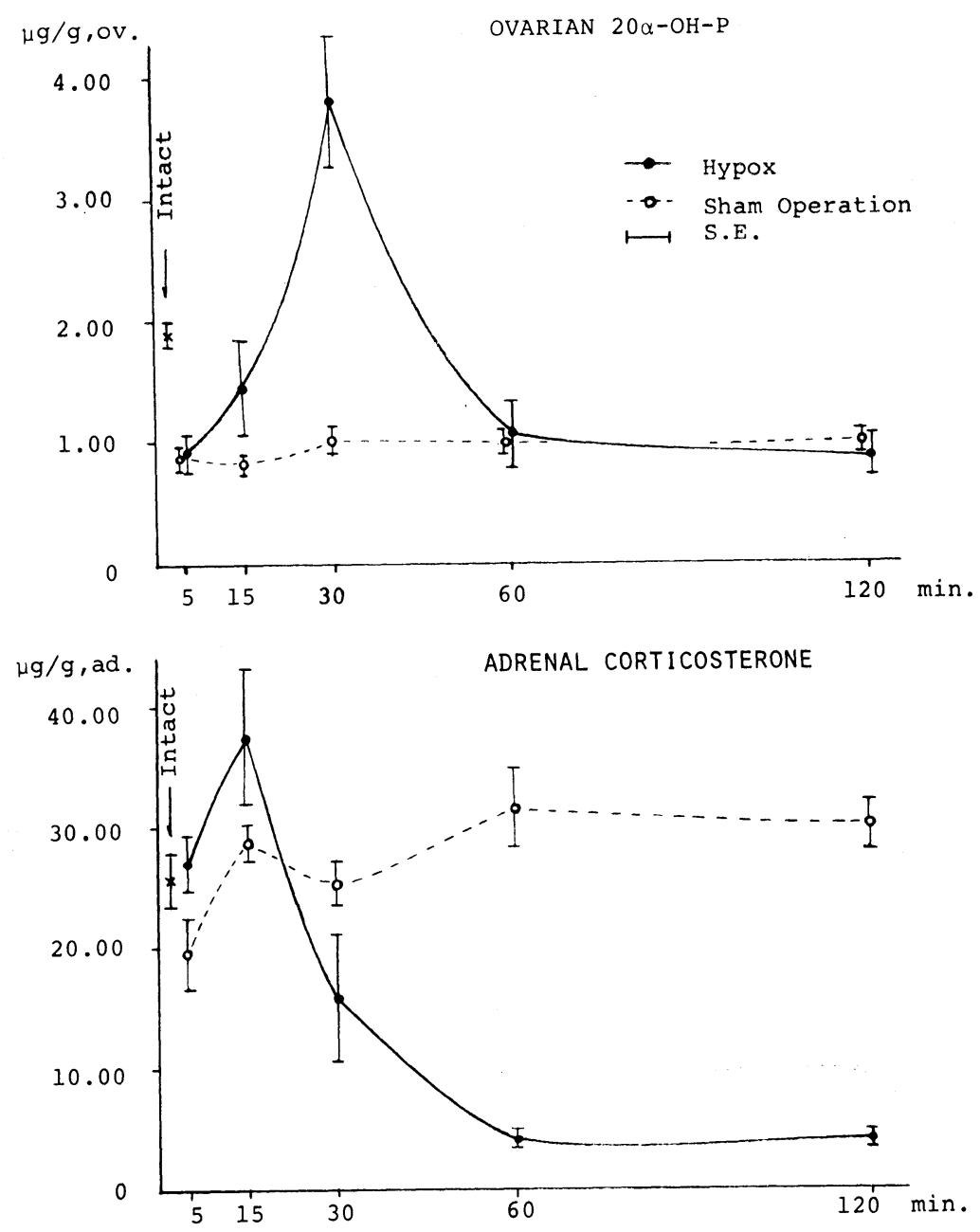

Fig. 4. Concentrations of ovarian 4-pregnen-20 $\alpha$-ol-3-one and adrenal corticosterone in rat at various times after the hypophysectomy as compared with sham operation.

costerone concentration and content as shown in Figure 4. These data show that alteration of ovarian $20 \alpha-\mathrm{OH}-\mathrm{P}$ level was absolutely different from that of adrenal corticosterone level in the sham operated rats as compared with those of hypophysectomized rats, respectively.

Through those experiments, it should be noted that a bulk of rats suffered from deep anesthesia, which was prolonged over $2 \mathrm{hr}$ owing to the doses for hypophysectomy.

Experiment 4: Ovarian and adrenal weight in rat at various times after the hypo- physectomy (Fig. 5)

Significant low levels were found in ovarian weight at $15 \mathrm{~min}(56.0 \pm 2.51 \mathrm{mg})$ and $30 \mathrm{~min}$ $(54.2 \pm 3.89 \mathrm{mg})$ after the hypophysectomy as compared with those of intact rats $(71.6 \pm$ $1.84 \mathrm{mg}$ ). After that ovarian weight showed a clear trend to decrease with time in all the cases from $1 \mathrm{hr}$ to 10 days following the operation. The decrease began to be found more significant than in intact rats after 1 day $(48.8 \pm 5.49 \mathrm{mg}) \quad(\mathrm{P}<0.01)$ to 10 days $(28.5 \pm 2.72 \mathrm{mg})(\mathrm{P}<0.001)$ following the 

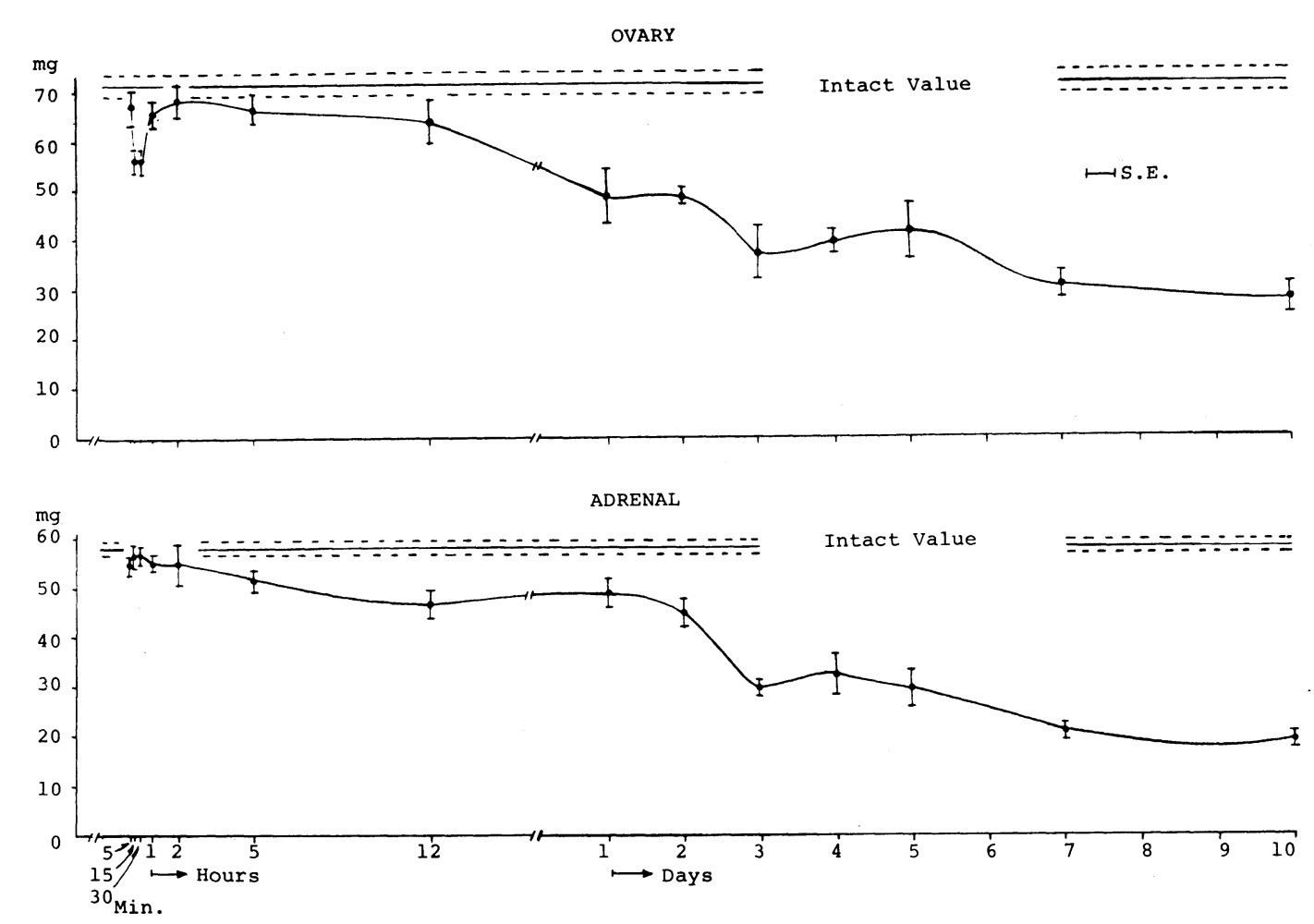

Fig. 5. Ovarian and adrenal weights in rat at varous times after the hypophysectomy.

operation. Similarly, more progressive decrease was observed in the adrenal weights from $5 \mathrm{~min}$ to 10 days after the hypophysectomy than in the intact control (58.5 \pm $1.21 \mathrm{mg})$ and significantly lower value was found in the former than in the latter from 12 hr $(46.8 \pm 2.48 \mathrm{mg})(\mathrm{P}<0.05)$ to 10 days $(19.0 \pm 1.29 \mathrm{mg})(\mathrm{P}<0.001)$. In contrast to ovarian weight, no significant decrease was found in adrenal weight at $15 \mathrm{~min}(56.2 \pm$ $2.29 \mathrm{mg})$ and $30 \mathrm{~min}(56.6 \pm 1.43 \mathrm{mg})$ following the hypophysectomy as compared with intact rats $(58.5 \pm 1.21 \mathrm{mg})$.

It should be emphasized from these results obtained from Exp. 1 4 that two distinct facts may be assumed; one is that endogenous steroid seems still working at least four days after hypophysectomy in the ovary, and the other is that, in the adrenal gland, it immediately declines up to $60 \mathrm{~min}$ after the operation.

\section{Effects of Pituitary Gonadotropin}

Experiment 5: Alteration of ovarian 20 $\alpha$ $\mathrm{OH}-\mathrm{P}$ at various time intervals after $\mathrm{FSH}$ or LH administration in hypophysectomized rats (Fig. 6)

FSH and/or LH was intravenously given to hypophysectomized rats. In order to make valid comparisons between the hypophysectomized plus saline (vehicle)-treated and hypophysectomized plus FSH or LH or FSH + LH treated animals, ovarian $20 \alpha-\mathrm{OH}-$ $P$ levels were investigated repeatedly. Since the differences between hypophysectomized plus saline treated group and hypophysectomizeduntreated group were not significant at any times from 5 to $180 \mathrm{~min}$ after injection, the values obtained from hypophysectomized plus saline group was excluded in Figure 6 and 7.

FSH Administration; A statistically significant increase $(\mathrm{P}<0.001 ; 5,10,120 \mathrm{~min})$, 

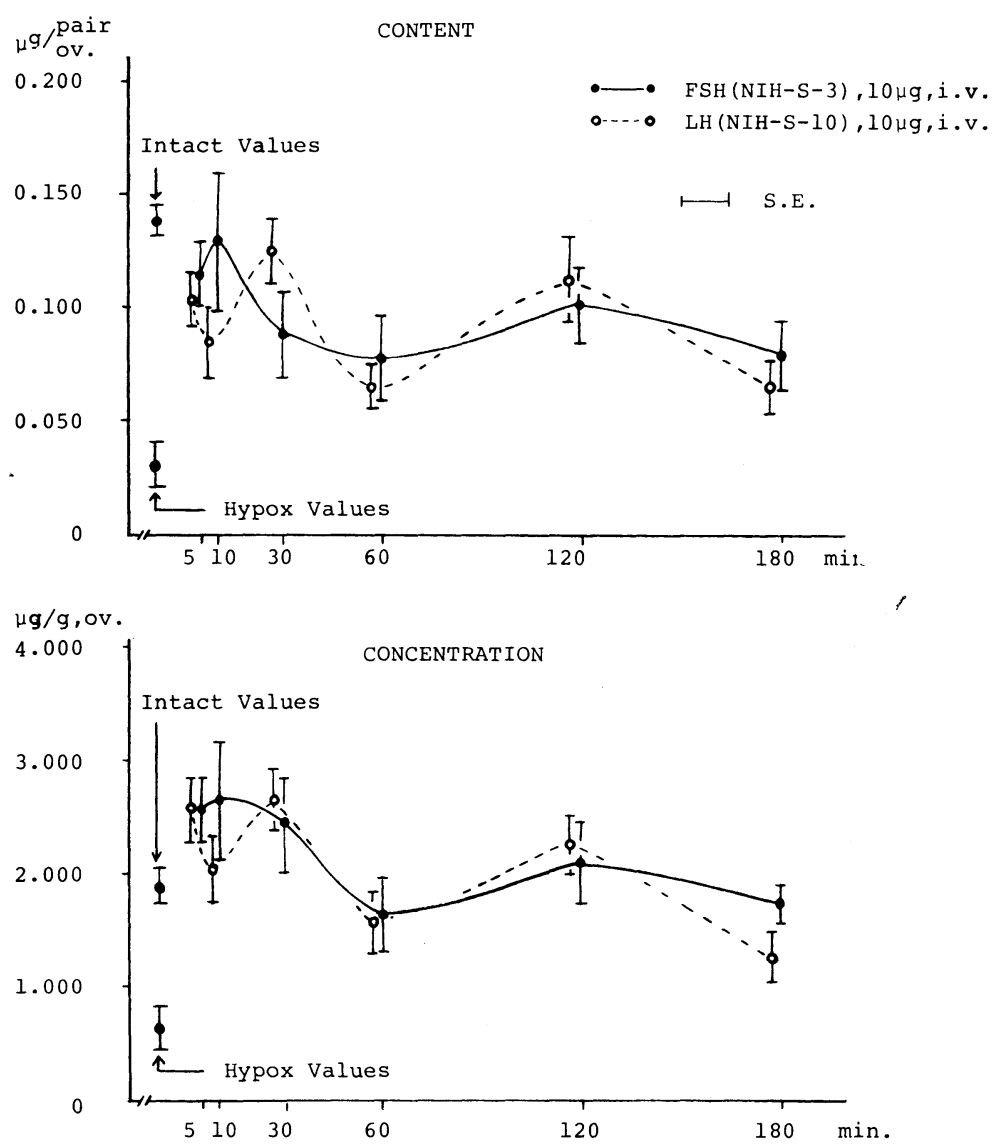

Fig. 6. Alteration of ovarian 4-pregnen-20 $\alpha$-ol-3-one at various times after the pituitary gonadotropin treatment by the hypophysectomized rats.

Rats were used 6 days after hypophysectomy.

$(\mathrm{P}<0.01 ; 30,180 \mathrm{~min}),(\mathrm{P}<0.05 ; 60 \mathrm{~min})$ was found in $20 \alpha-\mathrm{OH}-\mathrm{P}$ contents at $5,10,30$, 60,120 and 180 min after the FSH injection as compared with those of hypophysectomizeduntreated rats as shown in Figure 6. On the other hand, there were no significant difference between intact and hypophysectomized plus FSH treated rats in $20 \alpha-\mathrm{OH}-\mathrm{P}$ contents at 5, 10,30 and 120 min after the injection though a statistically significant lower levels was shown in the latter at 60 and $180 \mathrm{~min}$. FSH treated group showed increase in the concentration of $20 \alpha-\mathrm{OH}-\mathrm{P}$, the differences being highly significant between hypophysectomized plus FSH treated group and hypophysectomized- untreated group at all observation times from 5 to $180 \mathrm{~min}$ as shown in Figure 6. These increased values reached a level comparable to that of the intact animals. Thus, any difference between hypophysectomized plus FSH treated group and intact group was not significant in the concentration of $20 \alpha \mathrm{OH}-\mathrm{P}$.

LH Administration; A statistically significant increase $(\mathrm{P}<0.001 ; 5,30$ and $120 \mathrm{~min})$, $(\mathrm{P}<0.01 ; 10 \mathrm{~min}),(\mathrm{P}<0.05 ; 60$ and 180 min) was found in the content of $20 \alpha-\mathrm{OH}-\mathrm{P}$ at $5,10,30,60,120,180$ min after LH injection over those of hypophysectomized-untreated rats (Fig. 6). Comparison of ovarian $20 \alpha-\mathrm{OH}-$ $\mathrm{P}$ content between hypophysectomized plus 


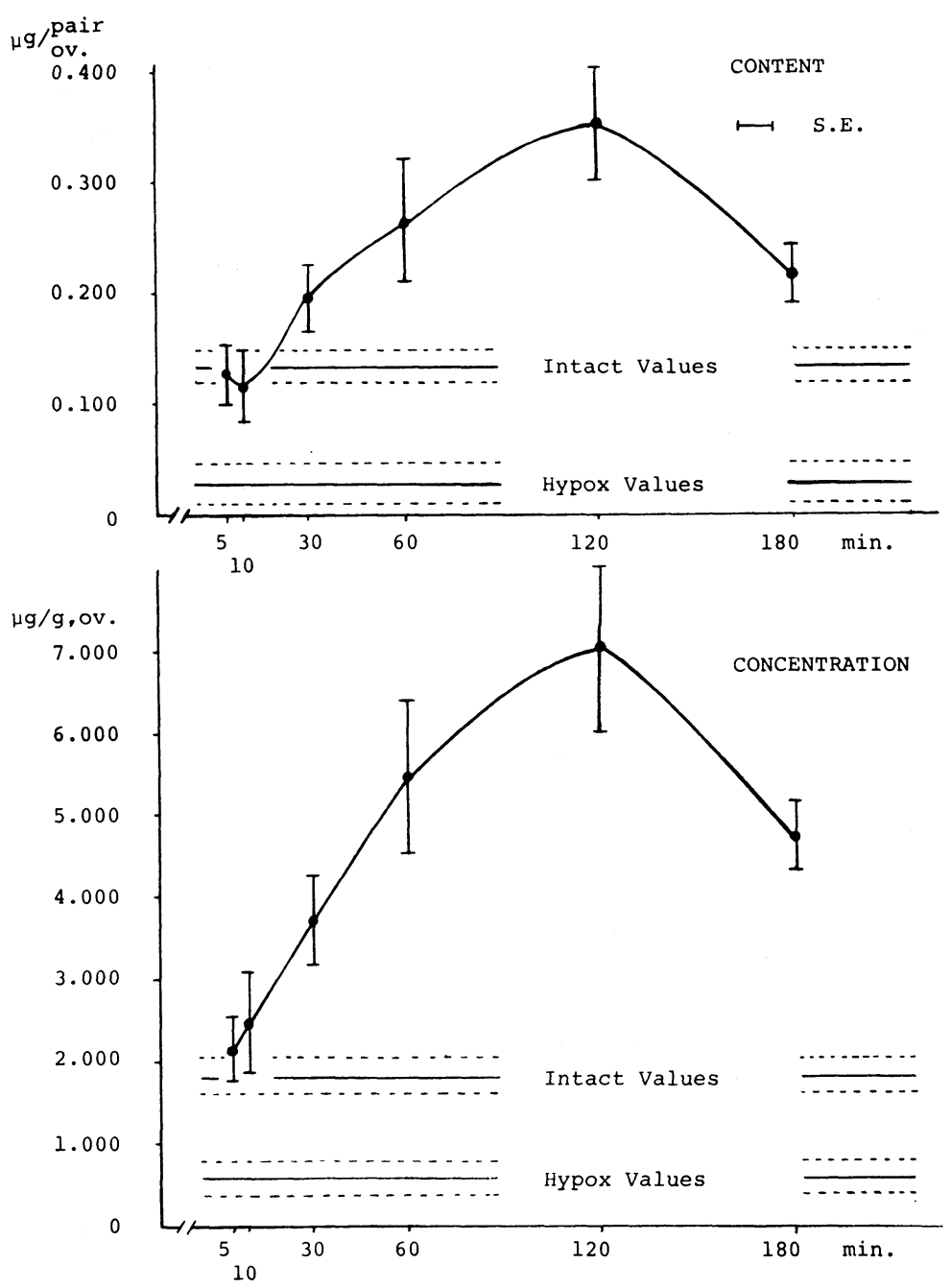

Fig. 7. Alteration of ovarian 4-pregnen-20 $\alpha$-ol-3-one at various times after the pituitary gonadotropin $(\mathrm{FSH}+\mathrm{LH})$ treatment by the hypophysectomized rats. Rats were used 6 days after hypophysectomy. Injection; FSH (NIH-S-3) $10 \mu \mathrm{g}+$ LH (NIH-S-10) $10 \mu \mathrm{g}$, i.v.

LH-injected and intact groups showed significantly lower values in the former at 5, 10, 60 and $180 \mathrm{~min}$ after $\mathrm{LH}$ injection, but no significant difference between them at 30 and $120 \mathrm{~min}$. Concentrations of $20 \alpha-\mathrm{OH}-\mathrm{P}$ in the hypophysectomized plus LH-injected group showed highly significant increase at all observation times after the $\mathrm{LH}$ injection over those of hypophysectomized-untreated group and these increased values reached a level comparable to that of intact rats as shown in Figure 6. It is now clear that function of ovary as evidenced by $20 \alpha-\mathrm{OH}-\mathrm{P}$ levels is influenced by FSH alone as well as LH.

Experiment 6: Alteration of ovarian 20 $\alpha-$ $\mathrm{OH}-\mathrm{P}$ at various times after the $\mathrm{FSH}+\mathrm{LH}$ injection in hypophysectomized rats (Fig. 7). Following the intravenous injection of a 
$\longrightarrow$ FSH $, 10 \mu \mathrm{g}+\mathrm{LH}, 10 \mu \mathrm{g}, \mathrm{i} . \mathrm{v}$.

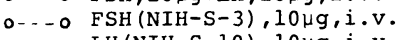
$x-x$ LH (NIH-S-10), $10 \mu g, i . v$.

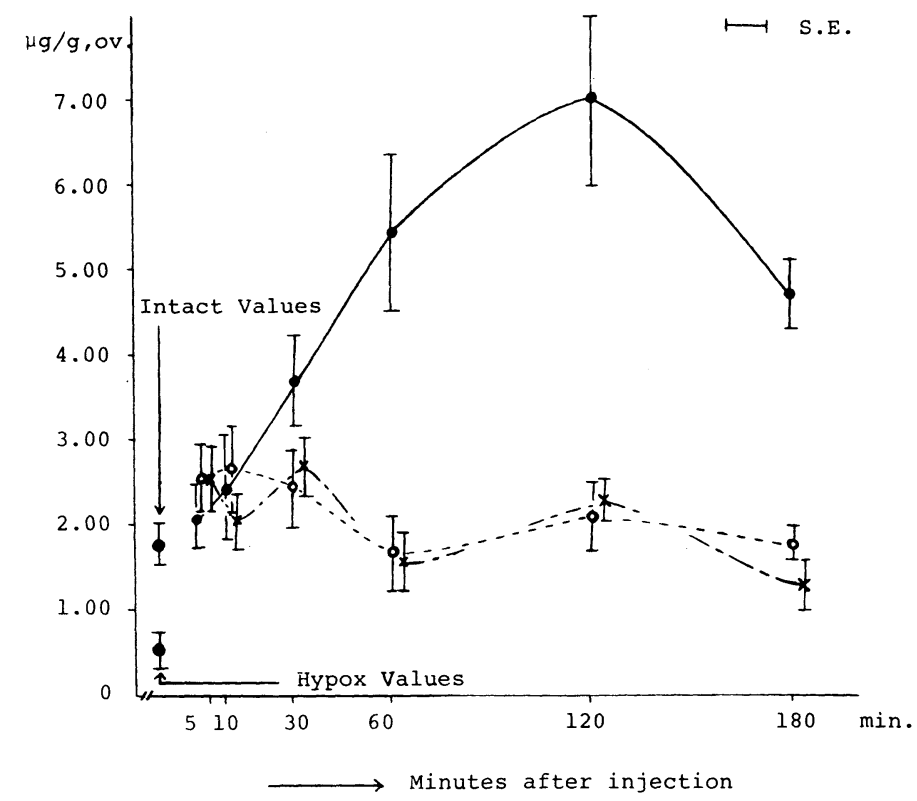

Fig. 8. Alteration of ovarian 4-pregnen-20 $\alpha$-ol-3-one at various times after the pituitary gonadotropin treatment by the hypophysectomized rats.

Rats were used 6 days after hypophysectomy.

combination of FSH and $\mathrm{LH}$, progressive increase was found in the ovarian $20 \alpha-\mathrm{OH}-\mathrm{P}$ in both contents and concentrations from 5 to $120 \mathrm{~min}$ after the injection, and difference between hypophysectomized plus FSH + LH-treated group and hypophysectomizeduntreated group was significant at all observation times after the injection. At $180 \mathrm{~min}$ when the values decreased in the former but still significantly higher than in the latter. Synergism was manifested that simultaneous effect of FSH plus LH on ovarian $20 \alpha-\mathrm{OH}-\mathrm{P}$ level was far greater than that of either FSH alone or LH alone. It seems likely that $20 \alpha$ OH-P levels both contents and concentrations may have attained the maximum $2 \mathrm{hr}$ after a single injection of FSH plus LH. Further, prior to the significant increase in $20 \alpha-\mathrm{OH}-\mathrm{P}$ appeared in the hypophysectomized plus
$\mathrm{FSH}+\mathrm{LH}$-treated group over the level in the intact group from 30 to $180 \mathrm{~min}$ after the injection, it reached in the former a level comparable to that of the latter at 5 and 10 min after the injection. It was thus realized that the response of ovarian $20 \alpha-\mathrm{OH}-\mathrm{P}$ genesis to exogenous FSH or $\mathrm{LH}$ or FSH + LH was very rapid, taking place within $5 \mathrm{~min}$.

\section{Discussion}

The data reported here represent preliminary evidence of the usefulness of a new finding for the time from hypophysectomy to ovarian function as evidenced by $20 \alpha-\mathrm{OH}-\mathrm{P}$. These results were compared with those of adrenal corticosterone. Further, the ovarian $20 \alpha-\mathrm{OH}-\mathrm{P}$ response to exogenous pituitary 


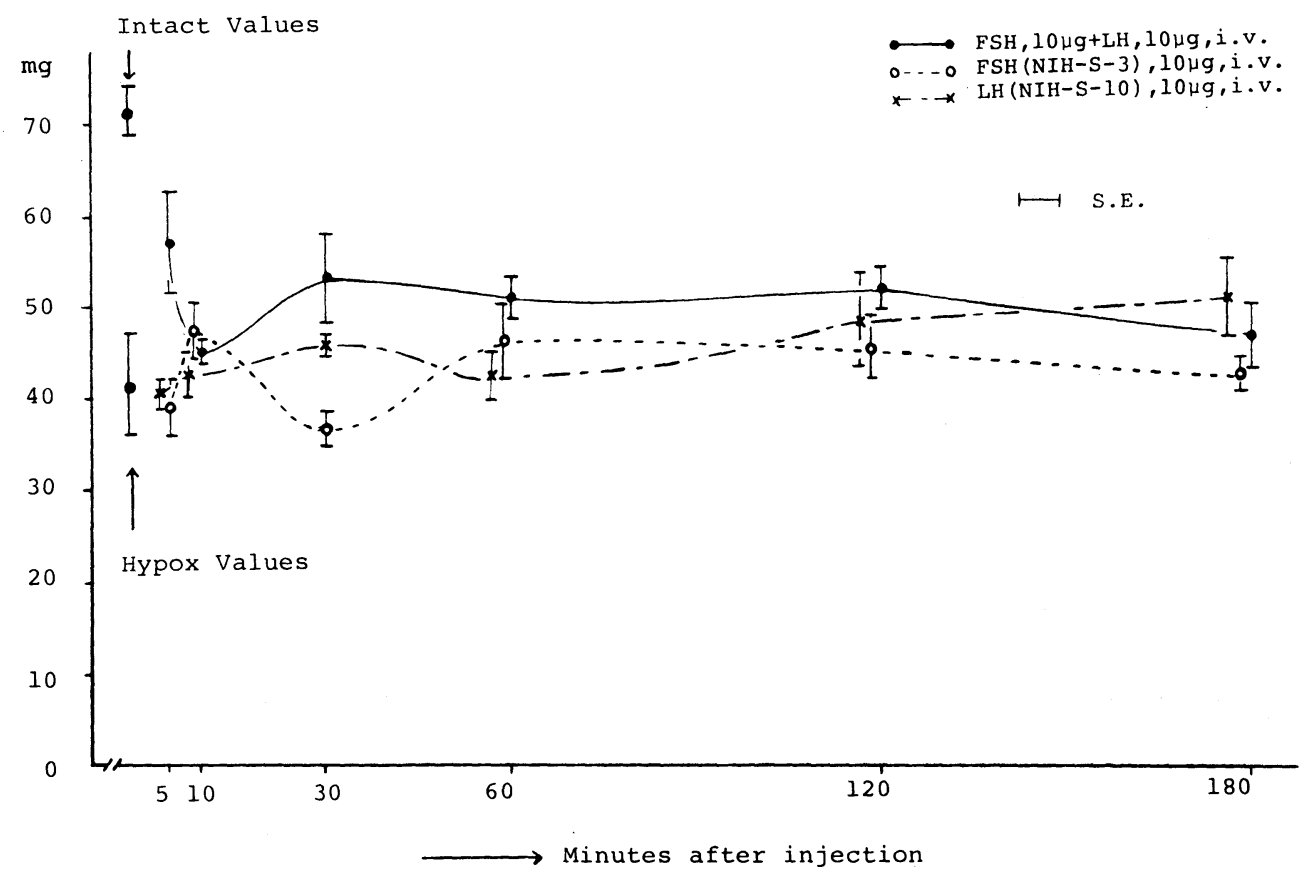

Fig. 9. Ovarian weight at various times after the pituitary gonadotropin (NIH) treatment by the hypophysectomized rats.

Rats were used 6 days after hypophysectomy.

gonadotropin by the hypophysectomized rats has been reported.

Firstly, alteration in $20 \alpha-\mathrm{OH}-\mathrm{P}$ level in rats at various short time intervals after hypophysectomy could be discussed (Fig. 4).

In ovarian $20 \alpha-\mathrm{OH}-\mathrm{P}$ level, a significant decrease was found at 5 min after the operation, then significant increase up to $30 \mathrm{~min}$, and again significant decrease at 60 and 120 min as compared with intact rats, while sham operated rats steadily showed, in contrast, significantly lower values in a short time from 5 to $120 \mathrm{~min}$ after the operation. In adrenal corticosterone level, a sharp decrease was found up to $60 \mathrm{~min}$ after the hypophysectomy as compared with intact animals except at 15 min when there was a trend to incrase, and the decrease continued more than 120 min until 10 days. On the contrary, sham operated rats showed no significant decrease in the adrenal corticosterone levels from a few min after the operation to $120 \mathrm{~min}$ as compared with that of intact animals.

In agreement with the adrenal data given by Lipscomb and Nelson (1962) Liddle et al. (1962) and Vernikos-Danellis (1969), though there were no direct information on it, the present results show that the appropriate time for ACTH bioassay is at least one hour after hypophysectomy.

There appears to be no reports in the literature on the possible use of the ovary regarding appropriate time after hypophysectomy for biological or biochemical assay. It should be emphasized from the present experiments that alteration of ovarian $20 \alpha-\mathrm{OH}-\mathrm{P}$ levels absolutely differed from that of adrenal corticosterone levels in rats at various short time intervals after hypophysectomy.

It can be suspected that the effects ascribed to hypophysectomy may be due to the surgical stimuli. This may raise an important problem. 
Fortunatly, since no significant differences were found between intact or sham operated animals at long time intervals, from $5 \mathrm{hr}$ to 10 days following the operation, the contributing effects of surgical trauma and anesthesia could be ruled out.

On the contrary, a significant differences appeared in the ovarian $20 \alpha-\mathrm{OH}-\mathrm{P}$ levels between the hypox, sham operation and intact samples at short times, from 5 to 120 min after the operation. In both hypox and sham operated rats, a bulk of animals had been sleeping up to over $2 \mathrm{hr}$ owing to pentobarbital anesthesia which was given for surgical operation of pituitary removal. It should be noted that all the decapitations were performed without anesthesia in rats at various times after the hypophysectomy. Thus, the effect ascribed to hypophysectomy such as significant decrease of ovarian $20 \alpha-\mathrm{OH}-\mathrm{P}$ within 5 or $15 \mathrm{~min}$ after both hypophysectomy and sham operation could be related to effect of pentobarbital which had been still working as prolonged action from the time when the animals had received hypophysectomy. It seems likely that prolonged action or duration of pentobarbital anesthesia may have exerted a depressing effect on ovarian function. It is, however, surprising that, against very low levels of $20 \alpha-\mathrm{OH}-\mathrm{P}$ found in the sham operated group $(5,15,30,60$ and $120 \mathrm{~min}$ after the operation) as well as in the hypox group (5, 15,60 and $120 \mathrm{~min}$ after the hypophysectomy) as compared with those of intact group, there was an exception at $30 \mathrm{~min}$ after the hypophysectomy when the level of $20 \alpha-\mathrm{OH}-\mathrm{P}$ was sharply increased to a significant high values over that of intact group. This rise may be explained by a immediate lack of continuous stimull namely, by the fact that removal of pituitary makes a shock on the pattern of steroidgenesis in the ovary, resulting in a reduced inhibitory action on steroid- $20 \alpha$ hydroxydehydrogenese $(20 \alpha-\mathrm{SDH})$ and/or a charge of protein binding of $20 \alpha-\mathrm{OH}-\mathrm{P}$ from the inactive to the active forms in the production site of $20 \alpha-\mathrm{OH}-\mathrm{P}$. This phenomenon was also observed in the adrenal corticosterone levels at $15 \mathrm{~min}$ after hypophysectomy. These findings may be explained in part by the observation of Clyne (1962) who reported "proportional sensitivity" and/or unidirectional rate sensitivity.

In addition, it seems that pentobarbital is capable of inhibiting ovarian function as evidenced by the alteration of $20 \alpha-\mathrm{OH}-\mathrm{P}$ levels as described above. This support Hixons' (1969) results. It has been well known that the activities of drug-metabolizing enzymes are higher in male rats than in female ones (Quinn et al., 1958; Gillette, 1963; Kato and Gillette 1965) and Fujii (1968) reported that sleeping time induced by pentobarbital remarkably prolonged in male rats after hypophysectomy whereas it showed the inclination to the prolongation in female rats. Further, the pentobarbital metabolizing enzyme activity in liver microsomes was apparently reduced in male rats after hypophysectomy, but female rats showed little change in enzyme activity. At present, it is likely that presence of pituitary plays an important role on the suppression, either direct or indirect, of ovarian function by the pentobarbital, but the site of action is obscure.

Secondly, alteration of ovarian $20 \alpha-\mathrm{OH}-\mathrm{P}$ level in rats at various long time intervals from $2 \mathrm{hr}$ to 10 days after hypophysectomy could be considered. The level of $20 \alpha-\mathrm{OH}-\mathrm{P}$ in the sham operated rat seems to be increased, run parallel to awaking from deep anesthesia by pentobarbital from 2 to $5 \mathrm{hr}$ at which time the level become comparable to that of intact animals. In hypox animals, at 5, 12 , and $24 \mathrm{hr}$ after the operation, $20 \alpha-\mathrm{OH}-\mathrm{P}$ level showed no significant difference from that of intact animals. Significant decrease was found on day 2 , but after that, the value was recovered up to a level of intact value on day 3 and then, it was gradually decreased to a very low level from 4 to 10 days after the hypophysectomy. In contrast to the alteration of $20 \alpha-\mathrm{OH}-\mathrm{P}$ level, no significant difference was found in the adrenal corticosterone level 
between the sham operated and intact animals from $60 \mathrm{~min}$ to 10 days. Further, the significantly decreased adrenal corticosterone level at $60 \mathrm{~min}$ remained unchanged up to 10 days after the hypophysectomy.

The most critical aspect of the timing, therefore, lies in the difference of the alteration of function in rats at various times after hypophysectomy between the ovary and the adrenal. Present results show clearly that the time after hypophysectomy is very important.

In the present trials, it was demonstrated as evidenced by $20 \alpha-\mathrm{OH}-\mathrm{P}$ levels that steroid biosynthesis and/or its metabolic alteration was still working in the ovary at least 4 days after hypophysectomy, namely, it is not absolutely true that pituitary support is essential for ovarian steroidgenesis or function. These are supported by the studies of Denamur and Manleon (1963), du Mesnil du Buisson and Leglise (1963) and Brinkley et al. (1964), who showed that the corpus luteum of the cycle is formed and maintained in the absence of the anterior pituitary in the pig and/or ewe. In the rabbit both the pituitary and uterus appear to exert a regulative role in luteal function (Loeb, 1923; Asdell and Hammond, 1933; Stormshak and Gasidda, 1964; Spies et al., 1968).

Hixon and Clegg (1969) found that the functional activity of sheep corpus lutaum is regulated by the anterior pituitary, and that both LH and prolactin are capable of stimulating progesterone output. They mentioned that treatment of animals with 3000 IU HCG, 50 $\mathrm{mg} \mathrm{LH}$ or $50 \mathrm{mg}$ prolactin resulted in significant increases in ovarian venous progesterone concentration within 10 to $20 \mathrm{~min}$. Their conclusions are based upon the observations that after a short period ( $4 \sim 5 \mathrm{hr})$ of pituitary deprivation, a significant depression of ovarian venous progesterone occurred. Thus the above mentioned their conclusion was made by the administration of gonadotropin or prolactin into ewe $5 \mathrm{hr}$ after hypophysectomy. These animals were hypophysectomized, cannulated with polyethylene tube into ovarian vein under continuos anesthesia of halothane with endotracheal intubation from the beginning to the collection of ovarian venous blood after intrajugularly injection of gonadotropin. Whether or not ovarian function is essentially supported by the anterior pituitary can not be confirmed by the observation of only $5 \mathrm{hr}$ after pituitary removal either with regard to corpus luteum function or to steroidgenesis. Furthermore, gonadotropin administration can throw into great confusion the steroidgenesis, which is orginated by the endogenous biosynthesis and also by exogenous effects. More evidences are indispensable to support their work.

Fortunately, it is established by the present data that endogenous ovarian steroidgenesis or its metabolism was still acting at least four days after hypophysectomy as evidenced by the $20 \alpha-\mathrm{OH}-\mathrm{P}$ levels observed from $5 \mathrm{~min}$ to 10 days after the operation. It is possible to assume that transient significant decrease is observed in the rat ovarian $20 \alpha-\mathrm{OH}-\mathrm{P}$ level within $5 \mathrm{hr}$ with a minimun at $2 \mathrm{hr}$ after hypophysectomy, which is identical with the appearance of progesterone levels according to their report, even though the interpretation may be varying. Subsequent significant rise and fall of the steroid at time intervals after hypophysectomy has been discussed already as above, and it can be emphasized that alteration of ovarian steroid following hypophysectomy is not so simple as that of adrenal corticoids. The most appropriate time after hypophysectomy must be 6 days when the ovary is no longer secreting significant quantity of ovarian steroid but when little sensitivity to gonadotropin appears to have been lost.

Figure 8 summerized the comparison of alteration in $20 \alpha-\mathrm{OH}-\mathrm{P}$ concentration after pituitary gonadotropin injection(s) in hypophysectomized rats. All animals received the injection 6 days after the operation. It is clear that the ovarian response to exogenous FSH or LH or FSH plus LH is very fast within 5 min as indicated by $20 \alpha-\mathrm{OH}-\mathrm{P}$ levels. These results show that, in hypophysectomized rat, 
FSH or LH alone can stimulate production of ovarian $20 \alpha-\mathrm{OH}-\mathrm{P}$, resulting in increase of the steroid up to a level comparable to that of intact animals. The combination of FSH plus LH injection markedly enhanced $20 \alpha-\mathrm{OH}-\mathrm{P}$ level, which was significantly higher than that of intact animals. Clearly, both pituitary gonadotropins are required in the rat ovary for substantial progestin secretion.

It is of interest that when significant increase occurred in the level of ovarian $20 \alpha-\mathrm{OH}-\mathrm{P}$, the ovarian weight was not significantly changed as late as 180 minutes after the injection of FSH or LH or FSH plus LH in the hypophysectomized animals (Fig. 9). It should be noted that both FSH and LH alone caused significant increase in concentration and contet of ovarian $20 \alpha-\mathrm{OH}-\mathrm{P}$ and that exogenous pituitary gonadotropin(s) is capable of acting on production site of $20 \alpha-\mathrm{OH}-\mathrm{P}$. But their possible significant physiological action on the ovarian weight is obscure.

Action of LH has been considered to be of primary importance in biosynthesis of both progesterone and $20 \alpha-\mathrm{OH}-\mathrm{P}$ in the ovary of rat (Savard et al. 1965; Armstrong and Black, 1966; Chatterton et al., 1968; Gospodarowicz, 1969), bovine (Mason and Savard, 1964; Koriz and Hall, 1965), and sow (Duncan et al., 1960). On the other hand, the role of FSH in the biosynthesis of progestin is poorly understood, since LH and FSH act synergistically to promote follicular development and steroidgenesis (Greep et al., 1942; Creep, 1961). A report by Gospodarowicz (1969) mentioned that bovine FSH had no effect on uterine growth and on interstitial tissue repair in the hypophysectomized female rat, and that it was also ineffective for the synthesis of progesterone at concentrations of less than $50 \mu \mathrm{g} / \mathrm{g}$ of tissue. Cook et al. (1967) summerized that progesterone synthesis in vitro is stimulated by LH, but not by FSH or prolactin.

Recently, Goldman and Mahesh, (1968) established that, in the rat, an acute release of FSH at proestrus may play a significant role in the ovulatory process. It is of special interest that Hirai et al. (1968b, 1970a) found that synthetic progestin, norethynodrel, does interfere in vivo directly with the response of the ovarian $20 \alpha-\mathrm{OH}-\mathrm{P}$ synthesis to exogenous FSH and LH in the hypophysectomized rat, suggesting that the effect of synthetic progestin on the mechanism of ovulation inhibiting action may involve inhibition of the biosynthesis of $20 \alpha-\mathrm{OH}-\mathrm{P}$. Furthermore, Hashimoto et al. (1968) reported that a large amount of $20 \alpha-\mathrm{OH}-\mathrm{P}$ is secreted prior to ovulation in adult cycling rats and the evidence was presented by Hilliard et al. (1967) that $20 \alpha-\mathrm{OH}-\mathrm{P}$ functions as a positive feed-back agent to prolong and heighten $\mathrm{LH}$ discharge in the mated rabbit. Present paper, FSH (NIH-S-3) obtained from NIH contained less than $0.0044 \mathrm{LH}$ relative potency to that of 1.1 FSH. It was demonstrated that the rise of $20 \alpha-\mathrm{OH}-\mathrm{P}$ could not have been solely due to contamination of LH with injected FSH, since the level of $20 \alpha-\mathrm{OH}-\mathrm{P}$ was not shown significantly increased by the injection of a dose of $50 \mathrm{ng} \mathrm{LH}$ in preliminary experiment.

It is now clear from the present results that FSH alone can act as stimulator of biosynthesis of $20 \alpha-\mathrm{OH}-\mathrm{P}$ as well as LH in hypophysectomized rats. Acute release of pituitary FSH occurs approximately concurrently with the ovulatory surge of $\mathrm{LH}$ (Goldman and Mahesh, 1968). If FSH is acutely released a few hours prior to ovulation and a large amount of $20 \alpha-\mathrm{OH}-\mathrm{P}$ is secreted prior to ovulation, FSH is indispensable for progestin biosynthesis like LH involved in the ovulatory process FSH regulating the functional aspects injoint action with LH.

The 20 -OH-P levels in ovarian venous blood and ovarian tissue were greater than those of progesterone throughout the estrous cycle (Hashimoto et al., 1968; Hirai et al., 1968c). The secretory rates of both progestins, $20 \alpha-\mathrm{OH}-\mathrm{P}$ and progesterone showed similar trends during the estrous cycle (Fajer et al., 1967). Present results demonstrate that there was no significant difference in the ova- 
rian $20 \alpha-\mathrm{OH}-\mathrm{P}$ between diestrus and proestrus, in the cycling Wistar strain. This supports Hashimoto's observation (1968). In general, both progestin levels in ovary were shown low in estrus and high in proestrus and diestrus (Hirai et al., 1968c, 1969a, 1969b; Hashimoto et al., 1968). High levels in proestrus occured at the same time with the release of anterior pituitary ovulating hormone ( $\mathrm{LH})$ into the blood (Ramirez and MeCann, 1964). However, what FHS contributes to synergism between these two gonadotropins has been more difficult to ascertain by estrous cycle variation. The present study suggests that the function of ovary as evidenced by $20 \alpha-\mathrm{OH}-\mathrm{P}$ levels is influenced distinctly by the FSH as above mentioned.

Effects of estrous cycle variations on the production and secretion of corticosterone was reported by Pincus and Hirai (1964), who mentioned that a significant difference was found the production of corticosterone in intact rats between in diestrus and in estrus. The present data showed that no significant difference was found in the ovarian $20 \alpha-\mathrm{OH}-\mathrm{P}$ level between diestrus and proestrus. These results together with previous reports (Hirai et al., 1968c; Hirai et al., 1969b) showed the evidence which is contrary to callardis (1965) interpretation of estrous cycle and adrenal corticoids.

\section{Acknowledgments}

We are indebted to the National Institute of Health in USA for thier kindly gift of international standard of FSH and LH.

\section{References}

Armstrong, D. L. and D. L. Black (1966). Endocrinology 78, 937.

Asdell, S. A. and J. Hammond (1933). Amer. J. Physial. 103, 600.
Brinkley, H. J., H. W. Norton and A. V. Nalbandov (1964). Endocrinology 74, 9.

Callard, G. V., I. P. Callard and J. H. Leathem (1965). Proc. Soc. Exp. Biol. Med. 118, 745 .

Chatterton, R. T. Jr., G. J. Macdonald and R. O. Greep (1968). Enodcrinology 83, 1.

Clyne, M. (1962). Annual. N. Y. Acad. Sci. 98, 806.

Cook, B., C. C. Kaltenbach, H. W. Norton and A. V. Nalbandov (1967). Endocrinology 81, 573.

Denamur, R. and P. Manleon (1963). C. R. Acad. and Sci. (Paris) 257, 264.

du Mesnil du Buisson, F. (1961). Ann. Biol. Anim. Bio-Chem. Biophys. 1, 105.

du Mesnil du Buisson, F. and P. C. Leglise (1963). C. R. Acad. Sci. (Paris) 257, 261.

Duncan, G. W., A. M. Bowerman, W. R. Hearn and R. M. Melampy (1960). Proc. Soc. Exp. Biol. Med. 104, 17.

Fajer, A. B. and C. A. Barraclough (1967). Endocrinology 81, 617.

Fujii, E., (1968). J. of Tokyo Women's Medical College 38(No. 11), 772.

Gillette, J. R. (1963). Progr. Drug. Res. 6, 39.

Ginther, D. J. (1967). J. Anim. Sci. 26, 578.

Goldman, B. D. and V. B. Mahesh (1968). Endocrinology 83, 97.

Gospodarowicz, D. (1969). Acta Endocrinol. 62, 39.

Greep, R. O., H. B. Van Dyke and B. F. Chow (1942). Endocrinology 30, 635.

Greep, R. O. In Young, W. C. (ed.) Sex and Internal Secretion, Baltimore, p. 240 (1961).

Hashimoto, I., D. M. Henrichs, L. L. Anderson and R. M. Melampy (1968). Endocrinology 82, 333.

Hilliard, J., T. Penardi and C. H. Sawyer (1967). Ibid. 80, 901.

Hilliard, J., H. G. Spies, L. Lucas and C. H. Sawyer (1968). Ibid. 82, 122.

Hirai, M., Y. Morita and T. Nakao (1968a) Perspectives in Biol. Med. (Chicago) 11, 427.

Hirai, M., Y. Morita and T. Nakao (1968b) Ibid. 11, 441.

Hirai, M., Y. Masubuchi and T. Nakao 
(1968c). Folia Pharmacologica Japon. 64 73.

Hirai, M., Y. Masubuchi and T. Nakao (1969a). Ibid. 65, 209.

Hirai, M., Y. Masubuchi and T. Nakao (1969b). Endocrinol. Japon. 16, 55.

Hirai, M., Y. Masubuchi and T. Nakao (1970a). Folia Endocrionol. Japon. 45, 1362. (In Japanese)

Hirai, M. and T. Nakao (1969). Except. Med. Intern. Congr. Series III Intr. Congr. on Hormonal Steroids (Humberg), 3, 92.

Hixon, J. E. and M. T. Clegg (1969). Endocrinology 84, 828.

Kato, R. and J. R. Gillette (1965). Pharmacol. Exptl. Therap. 151, 279.

Kidwell, W. R., K. Jr. Balogh and W. G. Wiest (1966). Endocrinology 79, 352.

Koritz, S. B. and P. F. Hall (1965). Biochemistry (Wash.) 4, 2740.

Liddle, G. W., D. Island and C. K. Meodor (1962). Recent Progr. Hormone Res. 18, 125.

Lipscomb, H. S. and D. H. Nelson (1962). Endocrinology 71, 13.

Loeb, L. (1923). Proc. Soc. Exp. Biol. Med. 20, 441.

Mason, N. R. and K. Savard (1964). Endocrinology 74, 664.
Nakao, T. and M. Hirai (1961). Jikei Med. J. $8,151$.

Nakao, T., M. Hirai and Y. Urata. Proc. 3rd Asia et Ocenia Congr. of Endocrinol., Manila. p. 702 (1967).

Pincus, G. and M. Hirai (1964). Acta Endocrinol. (Kopenhagen), Suppl. 90, 191.

Quinn, G. P., J. Axelrod and B. B. Brodie (1958). Biochem. Pharmacol. 1, 152.

Ramirez, V. D. and S. M. McCann (1964). Endocrinology 74, 814.

Savard, K., J. M. Marsh and B. F. Rice (1965). Recent Progr. Hormone Res. 21, 285.

Sekiyama, S., M. Hirai and T. Nakao (1968a). Jikei Med. J. 15, 271.

Sekiyams, S., M. Hirai and T. Nakao (1968b). Ibid. 15, 278.

Sekiyama, S., M. Hirai and T. Nakao (1969). Ibid. 16, 1.

Smith, P. E. and W. E. White (1931). JAMA 97, 1861.

Spies, H. G., D. R. Warren and H. T. Gier (1967). Endocrinology 81, 1435.

Spies, H. G., J. Hilliard and C. H. Sawyer (1968). Ibid. 83, 291.

Stormshak, F. and L. E. Casidda (1964). Ibid. 75, 321.

Vernikos-Danellis, J. (1969). Ibid. 84, 1507. 